\title{
Study on Strength Characteristics by using Fully Recycled Coarse Aggregate Concrete at Various Atmospheric Conditions
}

\author{
P Ganga Prasad ${ }^{1}$ | S Naveen Kumar ${ }^{2}$
}

${ }^{1}$ PG Scholar, Department of Civil Engineering, Visakha Technical Campus, Andhra Pradesh, India.

${ }^{2}$ Assistant Professor, Department of Civil Engineering, Visakha Technical Campus, Andhra Pradesh, India.

To Cite this Article

P Ganga Prasad and S Naveen Kumar, "Study on Strength Characteristics by using Fully Recycled Coarse Aggregate Concrete at Various Atmospheric Conditions", International Journal for Modern Trends in Science and Technology, 6(8): $80-85,2020$

Article Info

Received on 16-June-2020, Revised on 05-July-2020, Accepted on 26-July-2020, Published on 02-August-2020.

\section{ABSTRACT}

A large amount of construction waste has been dramatically increased in the last decade and environmental concerns on the recycling of waste has been increased. Mostly nowadays developing countries are demolishing some million tons of concrete wastages from the old buildings. So they are using Recycled aggregates for future construction. In this paper recycled coarse aggregate used 100\%. In our research work, we have collected the demolition waste from our village cement concrete road was demolished for the purpose of renovation. The demolished road is of $M 20$ grade concrete and age of concrete is 8years.

Nowadays construction of any concrete structure requires huge amount of natural coarse aggregate. So they are using demolition waste, to reduce the cost of purchasing natural coarse aggregate.

Recycled coarse aggregate are separated from the demolished waste by using equipment's. To improve the quality of recycled coarse aggregate by using treatment method's. The recycled coarse aggregates are weak in drying of shrinkage and creep. To control the drying of shrinkage and creep by using fly ash etc. The strength characteristics of natural coarse aggregate and recycled coarse aggregates. Recycled coarse aggregate are successful utilization in many countries such as European, American and Russia. This paper present's the investigation of strength characterstics due to effect of various temperature changes such as sulphate attack, acid attack, sea water and normal water.

KEYWORDS: Natural aggregates, Recycled coarse aggregates, Surface treatment method, Hydrochloric acid, Sulfuric acid, compressive strength, flexural strength.

\section{INTRODUCTION}

Concrete is the most widely used construction material on this earth. In fact, concrete is used in virtually everything and there is still no substitute available for many of its applications. Without concrete, the community and society cannot exist.
Therefore, lots of researches are going to find the new varieties of concrete which are economical for the construction. All these researches are focused on the replacements of different ingredients of the concrete which makes the concrete cheaper and even stronger too. In a developing country like India, old and dilapidated structures are 
demolished for the purpose of building new and high rise structure to meet the population demand. As a result, considerably large amounts of debris and rubble get accumulated in cities. This waste generated during demolition is mainly in the form of aggregate and dust which are dumped into nearly empty pits or on lands, river beds, pasture lands and agriculture fields leading to wide spread environmental pollution. Development of infrastructure also increases the demand for production of concrete, which in turn increases the demand for supply of aggregates. Lack of availability of good quality aggregates within reasonable distance brings out the need to identify sources of new aggregate. The waste generated in the region has the potential to meet the aggregate demands for construction activities. The twin objectives of conservation of natural resources and pollution free environment may be achieved if demolished concrete is effectively utilized. The new construction using the demolish waste as aggregate both fine and coarse in making new concrete will provide a solution to the present problem.

The use of recycle aggregate concrete in construction industry is advantageous and economical. The waste from construction and demolition work is of large volume and increasing in time. To overcome this issue, sustainable concrete construction is one of the strategies to be considered by the construction industry. One way of achieving these is to introduce recycled aggregates from these wastes of construction and demolition works into the production of concrete. In some countries the government encourage the use of recycled and reuse materials for construction industry. The reuse of recycled aggregate (RA) is not a common practice in construction industry. Nowadays there is depletion of natural aggregates and time will come where the sources of natural aggregate will soon decrease and will encounter a reduction in its supply. There is a severe shortage of infrastructural facilities like houses, hospitals, roads etc. in India and large quantities of construction materials for creating those facilities are needed. The planning Commission allocated approximately $50 \%$ of capital outlay for infrastructure development in five year plans.
From environmental point of view, for production of natural aggregates of 1 ton, 0.0046 million ton of carbon emitted. Whereas for production of 1 ton recycled aggregate only 0.0024 million ton carbons is produced. Considering the global consumption of 10 billion tons/year of aggregate for concrete production, the carbon footprint can be determined for the natural aggregate as well as for the recycled aggregate(source: Hossam Z. El- Karmonty et al 2013). The use of recycled aggregate generally increases the drying shrinkage creep \& porosity to water \& decreases the compression strength of concrete compared to that of natural aggregate concrete. The use of recycled aggregate in replacing the normal coarse aggregates in concrete construction has become popular among researchers. They compare the performance and characteristics of the two aggregates used. Most researchers found that the performance of recycled aggregate used in concrete has low workability and less compressive strength. The reasons for these are smooth texture and round shape of RA, higher percentage of fine particles and high water absorption. Researchers claimed that recycled aggregate has more angular shape and rough surface texture compare to natural aggregate. The angular shape and rough texture of RA leads to better bond and higher strength of concrete. To increase the compressive strength, recycled aggregate should be oven dried condition that will create the interfacial bond between cement paste and aggregate particles.

\section{LITERATURE REVIEW}

Goudappa Biradar et al (2015) an investigated on "An Experimental Study on Recycled Coarse Aggregates" Many researchers state that the recycled aggregates that are obtained from concrete specimen make good quality concrete. For improving the quality of recycled coarse aggregate, various surface treatment methods such as washing the recycled aggregates with water and diluted acid were investigated. Strength properties of the treated and untreated coarse aggregate were compared. The results indicated that the compressive strength of recycle aggregate is found to be less than the natural aggregate. A lot of experiments have been made to 
investigate the strength behavior of recycled aggregate concrete using demolition waste. Tests results show that behavior of concrete like workability, variation of strength made with recycled aggregate is more or less similar to conventional concrete. Mix designs can be made using recycled aggregate for structural concrete elements instead of disposing off the recycled concrete to achieve economy.

Ravi patel et al (2013) an investigated on "Experimental investigation or recycled coarse aggregate replaced for natural coarse aggregate in concrete" in general, present status \& utilization of recycled coarse aggregate in India with their future need is discussed. This Research Paper reports the basic properties of recycled coarse aggregate. It also compares these properties with natural aggregates. Basic changes in all aggregate properties were determined. Basic concrete properties like compressive strength, workability etc. are explained here for different combinations of recycled course aggregate with natural aggregate. The experimental results show that the early compressive strength of concrete made of natural coarse aggregate and recycled coarse aggregate is approximately same. In compaction factor test at the replacement of $40 \%$ of Recycled Aggregate the compaction factor value is maximum, the highest compacting factor ratio is 0.90 . So we can say that at the replacement of $40 \%$ recycled aggregate concrete is more workable. The compression test result indicates an increasing trend of compressive strength in the early age of the concrete specimens with $60 \%$ recycled aggregates. However, it shows that the strength of recycled aggregate specimens were gradually increase up to $40 \%$ replacement of recycled aggregate $\&$ then it decreases at the $100 \%$ replacement of recycled aggregate after 28 days. The target strength for $\mathrm{M} 40$ grade is $48.25 \mathrm{MPa}$ that are achieved for all the specimens tested in the study. The results also show that the concrete specimens with $40 \%$ replacement of recycled aggregate get the highest strength when compared to the concrete specimens with different percentage of recycled aggregate. From the obtained result, it is possible to use $40 \%$ recycled aggregate for higher strength of concretes.
Sudhir p.patil et al (2013) an investigated on "Recycled coarse aggregates" The slump of the normal concrete is observed to be less than the recycled one. Split tensile test shows that concrete has good tensile strength when replace up to $25-50 \%$.Due to lack of treatment process for RCA adequate strength is not achieved but by applying more advanced and sophisticated treatment process the strength can be improved.

G. Murali et al (2012) an investigated on "Experimental study on recycled aggregate concrete" However the strength of recycled aggregate concrete can be improved by the water and acid treatments such as hydrochloric and sulfuric acid.

Sagoe et al (2002) stated that the difference between the characteristic of fresh and hardened recycled aggregate concrete and natural aggregate concrete is relatively narrower than reported for laboratory crush recycled aggregate concrete mixes. There was no difference at the $5 \%$ significance level in concrete compressive and tensile strength of recycled concrete and control normal concrete made from natural aggregate.

Poon (2002) reported that there were not much effect of the compressive strength of brick specimens with the replacement of $25 \%$ and $50 \%$ of recycled aggregate. But when the percentage of recycled aggregate replacement increased, the compressive strength of the specimens was reducing.

Mandal et al (2002) also found that there will no effects on the concrete strength with the replacement of $30 \%$ of recycled aggregate. But the compressive strength was gradually decreasing when the amount replacement of recycled increased. They concluded that the properties and the strength characteristic of recycled aggregate concrete were deficiency when compared to the specimens that made by the natural aggregate.

Limbachiya et al (2000) found that recycled concrete aggregate had 7 to $9 \%$ lower relative density and 2 times higher water absorption than natural aggregate. According to their test results, it shown that there was no effect with the replacement of $30 \%$ coarse recycled concrete aggregate used on the ceiling strength of concrete. It also mentioned that recycled concrete aggregate could be used in 
high strength concrete mixes with the recycled concrete aggregate content in the concrete.

\section{EXPERIMENTAL STUDIES}

\section{Cement}

53 grade OPC cement is used in the present work. The properties of cement are determined from the laboratory investigations. The results of tests conducted on cement are presented in Table 4.1, along with the permissible limits for ascertaining quality of cement.

\begin{tabular}{|c|c|c|}
\hline Properties & Results & $\begin{array}{c}\text { Permissible limit } \\
\text { as per } \\
\text { IS:8112-1989 }\end{array}$ \\
\hline $\begin{array}{l}\text { Fineness of } \\
\text { Cement }\end{array}$ & $6.3 \%$ & $\begin{array}{c}\text { Not more than } 10 \\
\%\end{array}$ \\
\hline $\begin{array}{c}\text { Normal } \\
\text { consistency }\end{array}$ & $33 \%$ & $x_{1}$ \\
\hline $\begin{array}{l}\text { Specific } \\
\text { gravity }\end{array}$ & 3.03 & - \\
\hline $\begin{array}{c}\text { Initial Setting } \\
\text { Time }\end{array}$ & $98 \mathrm{~min}$ & $\begin{array}{l}\text { Should not be less } \\
\text { than } 30 \mathrm{~min}\end{array}$ \\
\hline $\begin{array}{c}\text { Final Setting } \\
\text { Time }\end{array}$ & $348 \min$ & $\begin{array}{c}\text { Should not be less } \\
\text { than } 600 \mathrm{~min}\end{array}$ \\
\hline $\begin{array}{l}\text { Compressive } \\
\text { strength }\end{array}$ & & \\
\hline $\begin{array}{l}\text { of cement } \\
\text { cubes for }\end{array}$ & & \\
\hline 3 days & $29.5 \mathrm{MPa}$ & $\begin{array}{c}\text { Should be }>27 \\
\mathrm{MPa}\end{array}$ \\
\hline 7 days & $38.4 \mathrm{MPa}$ & $\begin{array}{c}\text { Should be }>37 \\
\mathrm{MPa}\end{array}$ \\
\hline 28 days & $55.1 \mathrm{MPa}$ & $\begin{array}{c}\text { Should be }>50 \\
\mathrm{MPa}\end{array}$ \\
\hline
\end{tabular}

Physical Properties of Cement

\section{Coarse Aggregate}

A natural and recycled aggregate were used in this study. Natural coarse aggregate NCA) used was from an established quarry satisfying the requirements of IS 383:1970. Totally, two different nominal sizes of coarse aggregate were selected as $20 \mathrm{~mm}$ and $10 \mathrm{~mm}$. Recycled coarse aggregate (RCA) was obtained from manual breaking of crushed concrete cubes in Anakapalli . The aggregate was sieved through a standard set of sieves to produce an aggregate of $20 \mathrm{~mm}$ and $10 \mathrm{~mm}$ size graded metal.

\begin{tabular}{|c|c|c|}
\hline $\begin{array}{c}\text { Physical } \\
\text { properties }\end{array}$ & Natural Coarse & Recycled Coarse \\
\hline $\begin{array}{c}\text { Maximum } \\
\text { nominal size }\end{array}$ & Aggregate (NAC) & Aggregate(RAC) \\
\hline graded(mm) & 20 & 20 \\
\hline Specific gravity & 2.88 & \\
\hline
\end{tabular}

\begin{tabular}{|c|c|c|}
\hline $\begin{array}{c}\text { Bulk density } \\
\text { (loose }\end{array}$ & 1534.75 & 144.29 \\
\hline )kg/m3 & & \\
\hline Bulk density & 1778.29 & 1592.67 \\
\hline (rodded)kg/m3 & & $0.80 \%$ \\
\hline $\begin{array}{c}\text { Water Absorption } \\
\text { percent (\%) } \\
\text { IS:2386 }\end{array}$ & $0.60 \%$ & \\
\hline (Part3)-1963 & & \\
\hline Impact value \% & $19.30 \%$ & $30.85 \%$ \\
\hline
\end{tabular}

\section{Fine Aggregate}

In the present study, river sand conforming to Zone II as per 383: 1970 was used as Conventional fine aggregate. The fine aggregate is clean, inert and free from organic matter, silt and clay. The fine aggregate was completely dried before use. The physical properties of the fine aggregate were given in Table 4.3 below

\begin{tabular}{|c|c|}
\hline Physical properties & Natural fine aggregate \\
\hline Particulars & River Sand \\
\hline Zone & Zone II \\
\hline Specific gravity & 2.86 \\
\hline Bulk density $(\mathrm{kg} / \mathrm{m} 3)$ & 1695 \\
\hline Fineness & 2.64 \\
\hline Water absorption & $0.60 \%$ \\
\hline
\end{tabular}

\section{RESULTS \& DISCUSSIONS}

Comparision between compressive strengths in different conditions

\begin{tabular}{|c|c|c|c|c|}
\hline Description & \multirow{2}{*}{\multicolumn{4}{|c|}{ 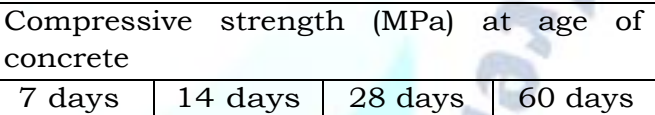 }} \\
\hline & & & & \\
\hline $\begin{array}{c}\text { Normal } \\
\text { condition }\end{array}$ & 20.9 & 28.9 & 32.12 & 30.3 \\
\hline $\begin{array}{c}(0 \% \\
\text { replacement })\end{array}$ & & & & \\
\hline $\begin{array}{l}\text { Normal } \\
\text { water }\end{array}$ & 15.9 & 21.3 & 24.4 & 23.6 \\
\hline$(100 \%$ & & $\mathrm{A}$ & 4 & \\
\hline replacement) & & & 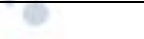 & \\
\hline Sea water & 14.05 & 19.40 & 23.54 & 22.96 \\
\hline$(100 \%$ & & & & \\
\hline replacement) & & & & \\
\hline $\begin{array}{c}\text { H2SO4 } \\
\text { sollution }\end{array}$ & 14.73 & 19.99 & 22.99 & 21.49 \\
\hline$(100 \%$ & & & & \\
\hline replacement) & & & & \\
\hline $\begin{array}{c}\text { HCL } \\
\text { solution }\end{array}$ & 15.82 & 21.90 & 25.34 & 24.22 \\
\hline
\end{tabular}




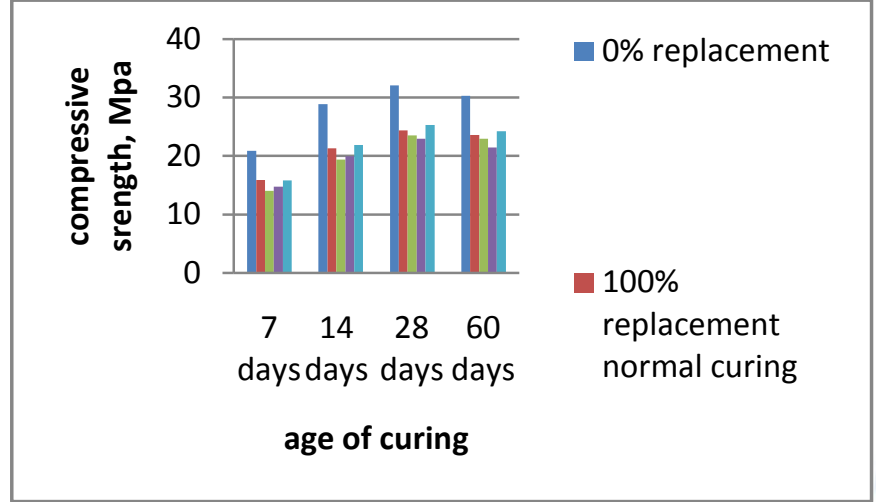

Comparison between flexural strengths in different conditions

\begin{tabular}{|c|c|c|c|c|}
\hline Description & \multicolumn{4}{|c|}{ Flexural strength (MPa) at age of concrete } \\
\hline & 7 days & 14 days & 28 days & 60 days \\
\hline $\begin{array}{c}\text { Normal } \\
\text { condition } \\
(0 \% \\
\text { replacement) }\end{array}$ & 2.48 & 3.43 & 3.9 & 3.79 \\
\hline $\begin{array}{c}\text { Normal } \\
\text { water } \\
(100 \% \\
\text { replacement) }\end{array}$ & 2.4 & 3.13 & 3.6 & 3.42 \\
\hline $\begin{array}{c}\text { Sea water } \\
(100 \% \\
\text { replacement })\end{array}$ & 2.10 & 2.25 & 2.41 & 2.36 \\
\hline $\begin{array}{c}\text { H2SO4 } \\
\text { sollution } \\
(100 \% \\
\text { replacement) }\end{array}$ & 2.31 & 2.7 & 2.76 & 2.74 \\
\hline HCL solution & 2.33 & 2.63 & 2.86 & 2.83 \\
\hline
\end{tabular}

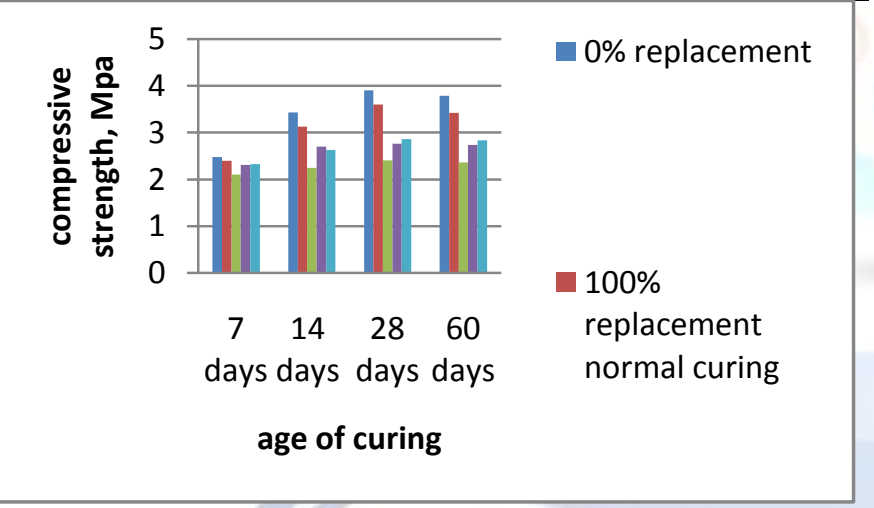

v. CONCLUSION

$>$ Based on the results of the experimental studies on M2O grade concretes with recycled and natural coarse aggregates and taking the effect of curing with normal water, sea water, sulfate attack and acid attack the following conclusions are drawn.

$>$ The Recycled aggregate satisfied the strength parameters for use as alternative to natural coarse aggregate in concrete making like temporary concretestructures low strength pavements (pedestrians) and village bathrooms.

\section{Conclusions on compressive strength}

$>$ A maximum reduction of about $26 \%$ was noticed in compressive strength when the entire coarse natural aggregate was replaced with RCA. The strength is achieved $74 \%$ in compressive strength in normal water curing. $>$ A maximum reduction of about $31 \%$ was noticed in compressive strength when the entire coarse natural aggregate was replaced with RCA. The strength is achieved 69\% in compressive strength in sea water curing.

$>$ A maximum reduction of about $29 \%$ was noticed in compressive strength when the entire coarse natural aggregate was replaced with RCA. The strength is achieved $71 \%$ in compressive strength in $\mathrm{H} 2 \mathrm{SO} 4$ sollution water curing.

$>$ A maximum reduction of about $22 \%$ was noticed in compressive strength when the entire coarse natural aggregate was replaced with RCA. The strength is achieved $78 \%$ in compressive strength in HCL sollution water curing.

$>$ A maximum reduction of about $27 \%$ was noticed in compressive strength when the entire coarse natural aggregate was replaced with RCA. The strength is achieved $73 \%$ in average compressive strength. These results may impact on durability studies.

\section{Conclusions on flexural strength}

$>$ A maximum reduction of about $11 \%$ was noticed in flexural strength when the entire coarse natural aggregate was replaced with RCA. The strength is achieved $89 \%$ inflexural strength in normal water curing.

$>$ A maximum reduction of about $36 \%$ was noticed in flexural strength when the entire coarse natural aggregate was replaced with RCA. The strength is achieved $64 \%$ in flexural strength in Sea water curing.

$>$ A maximum reduction of about $27 \%$ was noticed in flexural strength when the entire coarse natural aggregate was replaced with RCA. The strength is achieved $73 \%$ in flexural strength in $\mathrm{H} 2 \mathrm{SO} 4$ solution water curing.

$>$ A maximum reduction of about $25 \%$ was noticed in flexural strength when the entire coarse natural aggregate was replaced with RCA. The strength is achieved $75 \%$ in flexural strength in HCL solution water curing.

A maximum reduction of about $24.75 \%$ was noticed in flexural strength when the entire coarse natural aggregate was replaced with 
RCA. The strength is achieved $75.25 \%$ in average flexural strength. These results may impact on durability studies.

\section{REFERENCES}

[1] Abhiram . K and Saravanakumar . P .., Properties of Recycled Aggregate Concrete Containing Hydrochloric Acid Treated Recycled Aggregates.., 2015,ISSN: 09744290, Vol.8, No.1, pp 72-78

[2] Akshit dimri, Jay kar varshney, I-M Tech Civil Engg, G.B.P.U.A \& T Pantnagar, India..,Review on Strength of concrete in Sea Water.., ISSN:2278-0181, Vol.4, ISSUE 03.., march- 2015.

[3] Bhushan Rasik Kothari , Abhay Shelar.., Experimental Investigation of Recycle Concrete Aggregate, Volume 3 | Issue 02 | July 2016.

[4] Chetna M.Vyas , Prof.Jayeshkumar Pitroda.., Fly Ash and Recycled Aggregate in concrete :New Era for construction industries - A Literature Review.., Volume 4, issue 5-May 2013.

[5] Gangaram.S , Bhikshma.V, Janardhana.M.., Strength and durability aspects of recycled aggregate concrete, pISSN2321-7308.

[6] Goudappa Biradar Bheemanna Khandre Institute of Technology, Bhalki, Karnataka, INDIA ..,An Experimental Study on Recycled Coarse Aggregates, (Special Issue on NCRIET-2015) 6(2): 174-177(2015).

[7] Harsh S. Parekh, Prashant K. Bhuva, Vijay Kukadia, Jignesh H. Solanki.., the study of concrete behaviour prepared with chemically treated recycle aggregate: a review, Volume 3, Issue 1, January - 2016.

[8] Jignesh h. Solanki, Prashant K. Bhuva , Vijay Kukadia, Harsh S. Parekh , Noble Group of Institution.., the study of concrete behavior prepared with chemically treated recycle aggregate.., Volume 3,Issue 5, May -2016.

[9] Khaitan CK., Construction and demolition waste; Regulatory issues and initiatives of MoUD. Proc., Workshop on C\&D Waste Recycling, Organized by Indian Concrete Institute-Central Public Works Dept.,2013, New Delhi, India, 20-23.

[10] Kukadia.V.P Research scholar, Dr.D.N.prakesh, Head of Applied meachanics department, Sir BPTI Poltechnic , Bhavanagar, India.., Influence of Aggregates Trearment on Properties Concrete, Volume \& Issue no:3,March 201,pp 351-361.

[11] Manoj. B and Saravanakumar.P.., Effect of Sulfuric Acid Treated Recycled Aggregates on Properties of Concrete .., 2015,ISSN: 0974- 4290, Vol.8, No.2, pp476-482.

[12] Limbachiya.., Properties of Concrete Made With Recycled Coarse Aggregate.., ISSN (Online): 2347-1697, Volume 2 Issue 10 June 2015.

[13] Md. Moinul Islam, Md. Saiful Islam, Md. Al-Amin and Md. Mydul Islam.., Suitability of sea water on curing and compressive strength of structural concrete..,Journal of Civil Engineering (IEB), 40 (1) (2012) 37-45.

[14] Mohamed Arafa, Bassam A. Tayeh, Mamoun Alqedra, Samir Shihada1, Hesham ... Investigating the Effect of Sulfate Attack on Compressive Strength of Recycled Aggregate Concrete , (ISSN: 2180-3242) Vol 8, No 2, 2017.
[15] Murali G, VivekVardhan C, Gabriela Rajan G., Experimental study on recycled aggregate concrete. International Journal of Engineering

[16] Olutoge, F. Adeyemi and Amusan, G. Modupeola.., The Effect of Sea Water on Compressive Strength of Concrete .., ISSN (Online): 2319 - 6734, ISSN (Print): 2319 - 6726 www.ijesi.org Volume 3 Issue 7 July 2014 I PP.23-31.

[17] Prafulla Kumar Tiwari1, Dr. Raman Nateriya.., Replacement of recycled coarse aggregates with natural coarse aggregates in concrete, Volume-2, Issue-7, July 2016.

[18] Praveen Reddy.I, Ragavendra.S, Archanaa.., Experimental study on recycled coarse aggregate concrete, Indian J.Sci.Res. 17(2): 357 -360 2018.

[19] Preeti Tiwari, Rajiv Chandak, R.K. Yadav.., "Effect Of Salt Water On Compressive Strength Of Concrete".., ISSN : 2248-9622, Vol. 4, Issue 4( Version 5), April 2014, pp.38-42.

[20] Rahal K., Mechanical properties of concrete with recycled coarse aggregate.Building and Environment., 2007, 42, 407-415.

[21] Ravi patel, chetna m vyas \& darshana r bhatt.., experimental investigation for recycled coarse aggregate replaced for natural coarse aggregate in concrete.., Vol. 3, Issue 2, Jun 2013, 35-42.

[22] Sagoe, mandal.., Effect of Using Recycled Concrete as Coarse Aggregate on Tensile and Flexural Strength of Concrete.., Las Vegas,

[23] Saravanakumar, P., and Dhinakaran, G., (b), "Durability characteristics of recycled aggregate concrete", Structural Engineering and Mechanics, V. 47 , No. 5,2013 , pp. $701-711$.

[24] Saravanakumar, P., and Dhinakaran, G., "Durability aspects of HVFA based Recycled Aggregate Concrete", Magazine of Concrete Research, V. 66, No.4, 2014, pp. $186-195$.

[25] Shrinath.H Bharath Kumar, Sumit, Vinodkumar L.., Influence of Treatment Methods on Recycled Aggregate Concrete made with Recycled Coarse aggregate,ISSn:2455- 2631, May 2016 USDR.

[26] Sudhir P.Patil, Ganesh Single, Prashant D.Santhe.., Recycled Coarse Aggregates

[27] Sunil Kumar M. tech scholar, Dr. S.N. Sachdeva and Dr. Paratibha Aggarwal ,Professor, Civil Engineering Department, NIT Kuru kshetra, Haryana, India..,Effect of Sulphate Solution on Recycled Aggregate Concrete.

[28] Swathi maniya 1, Prof. Sagar Gawande , Prof. Yogesh Deshmukh.., Comparative Study of Effect of Salt Water and Fresh Water on Concrete.., e-ISSN: 2395 -0056 Volume: 04 Issue: 04 | Apr -2017 www.irjet.net p-ISSN: 2395-0072 